\title{
Chromatographic characterization of pyroligneous liquid obtained from carbonization of peach stone
}

The peach stone is considered an agroindustrial residue originating from the industrial process of peach in halves in syrup. It does not have an adequate destination its final disposal is incorrect and may cause contamination in the environmental compartments. In this way, the burning of this raw material as biomass enables its reuse, besides adding value to the residue. Among the processes used for the application of this residue is the carbonization process, which allows to obtain coproducts with higher added value, such as pyroligneous liquid, which represents a fraction of organic compounds condensed from the smoke emitted during carbonization. The quality of the liquid depends on the process conditions and the biomass used. Therefore, the objective of this study was to characterize the sample of pyrolignous liquid obtained from the carbonization of the peach stone, on an industrial scale, qualitative and semi quantitative. Preliminary characterization $(\mathrm{pH}$, conductivity, color, density and contents of tar, organic matter and acidity) and a chemical characterization by gas chromatography coupled to mass spectrometry (GC-MS) were performed. The liquid presented satisfactory results for the physico-chemical evaluations. Regarding the qualitative determination, it was possible to identify 49 compounds. Highlighting the phenols, with $44.90 \%$ of the number of compounds, mainly methoxyphenols. These are compounds with significant added value and industrial importance, indicating their use as raw material in the production of polymer resins, among other purposes.

Keywords: Biomass; Carbonization; Agroindustrial waste; Chromatography.

\section{Caracterização cromatográfica do líquido pirolenhoso obtido da carbonização do caroço de pêssego}

\begin{abstract}
A pedra de pêssego é considerada um resíduo agroindustrial originário do processo industrial de pêssego em metades em calda. Não possui um destino adequado seu descarte final é incorreto e pode causar contaminação nos compartimentos ambientais. Dessa forma, a queima dessa matéria-prima como biomassa possibilita sua reutilização, além de agregar valor ao resíduo. Entre os processos utilizados para a aplicação desse resíduo está o processo de carbonização, que permite obter co-produtos com maior valor agregado, como o líquido pirolímero, que representa uma fração dos compostos orgânicos condensados pela fumaça emitida durante a carbonização. A qualidade do líquido depende das condições do processo e da biomassa utilizada. Portanto, o objetivo deste estudo foi caracterizar a amostra de líquido pirolímero obtido a partir da carbonização da pedra de pêssego, em escala industrial, qualitativa e semiquantitativa. Foram realizadas caracterização preliminar ( $\mathrm{pH}$, condutividade, cor, densidade e conteúdo de alcatrão, matéria orgânica e acidez) e caracterização química por cromatografia em fase gasosa acoplada à espectrometria de massa (GC-MS). O líquido apresentou resultados satisfatórios para as avaliações físico-químicas. Quanto à determinação qualitativa, foi possível identificar 49 compostos. Destacando os fenóis, com $44,90 \%$ do número de compostos, principalmente metoxifenóis. São compostos com significativo valor agregado e importância industrial, indicando seu uso como matéria-prima na produção de resinas poliméricas, entre outros fins.
\end{abstract}

Palavras-chave: Biomassa; Carbonização; Resíduos agroindustriais; Cromatografia.

Topic: Desenvolvimento, Sustentabilidade e Meio Ambiente

Reviewed anonymously in the process of blind peer.

Lidiane Schmalfuss Valadão (iD

Instituto Federal Sul-rio-grandense, Brasil http://lattes.cnpq.br/0171832404544043 http://orcid.org/0000-0002-0476-0790

lidianeschmalfuss@hotmail.com

Caroline dos Santos Duarte (iD)

Instituto Federal Sul-rio-grandense, Brasil http://lattes.cnpq.br/2854030045109434 http://orcid.org/0000-0002-1002-8694

caroolsduarte@hotmail.com

Pedro José Sanches Filho (iD

Instituto Federal Sul-rio-grandense, Brasil http://lattes.cnpq.br/9785390634457316 http://orcid.org/0000-0002-9852-8940 pjsans@ibest.com.br
Received: $12 / 04 / 2019$

Approved: 27/05/2019
Referencing this:

VALADÃO, L. S.; DUARTE, C. S.; SANCHES FILHO, P. J.. Chromatographic characterization of pyroligneous liquid obtained from carbonization of peach stone. Revista Ibero Americana de Ciências Ambientais, v.10, n.3, p.207-218, 2019. DOI: http://doi.org/10.6008/CBPC2179$\underline{6858.2019 .003 .0018}$ 


\section{INTRODUCTION}

The amount of carbon gas emitted into the atmosphere is directly influenced directly by the of fossil fuels, consumption growth, industrial activities and methane gas production from the decomposition of the solid residues (DIAS, 2015). Among these activities, the energy generation from non-renewable sources has been the main cause of emission of greenhouse gases, elevating the risks of global warming. Starting from this fact, the search for alternative renewable and cleaner energy sources has been focus of several studies (SENA et al., 2014).

In this scenario, the biomass used as source of energy becomes a viable alternative for the substitution of the fossil fuels. The biomass is the biodegradable fraction of products or residues coming from the agriculture, forestry, industry or residences (DIMAKIS et al., 2011). Which contains energy stored in the form of carbohydrates that is released and used for generation of heat, electricity and production of liquid and gaseous fuels (FERREIRA et al., 2016).

Residues of the agribusiness have been widely studied in order to obtain co-products with higher added value, as the pyroligneous liquid, coal and gas (KOPP et al., 2015; HEYLMANN et al., 2015). In the southern area of Rio Grande do Sul, the woody endocarp (pit) of the fruit of Prunus persica (peach) (Fig. 1) constitutes an agroindustrial residue generated in large scale: about 4.048 tons a year of pit.

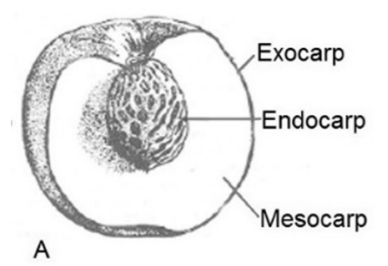

A

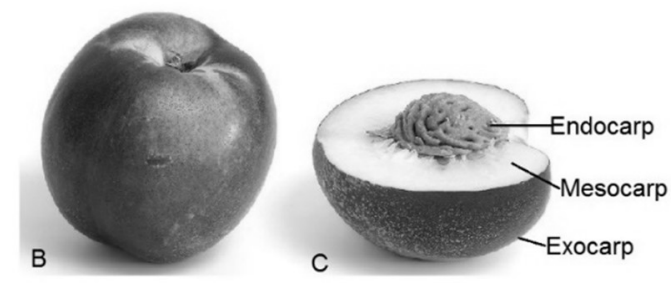

Fig 1: (a) Representation of the structure of the fruit Prunus persica; (b) The whole fruit; (c) Structure of the fruit in nature.

However, the core (peach stone) is not used industrially and has been discarded improperly, being exposed to the environment and suffering slow degradation, which can provoke contamination of the soil and the water resources. Considering the environmental impacts and the abundance of this biomass, the woody endocarp has been used in the generation of charcoal (HEYLMANN et al., 2015). In this case, the main chemical process used to convert biomass into a more useful energy form is carbonization. According to Bridgwater (2006) and Bae et al. (2011), in this technique, yields and quality are influenced by the process operating conditions, with degradation of organic constituents forming products in the gaseous, solid and liquid states.

According to SENA et al. (2014) approximately $30 \%$ volume of the burnt biomass is converted to coal with the remainder emitted into the atmosphere, aggravating the concentration of pollutant gases. The almost $70 \%$ residual obtained in the process of carbonization of biomass consists of a non-condensable (gases) and a condensable part, from which the pyroligneous liquid originates (TORRES et al., 2014). This is composed of the organic acid fraction, aqueous fraction and tar (MORVOVÁ et al., 2003; VIEIRA et al., 2015). The proportion of co-products generated varies according to the temperature, the type of process, the type 
of biomass and the equipment used. However, the pyroligneous liquid usually represents about $35 \%$ of the final product, but its economic potential has not been studied very well (SENA et al., 2014).

The use of this by-product causes a significant reduction of gaseous emissions from the carbonization technique and it has been becoming attractive as a source of chemical compounds and generation of new environmental impact reducing products. Aiming at the definition of different uses for products obtained in the carbonization process, such as: fuels; aromas; binders and resins; with emphasis on fertilizer production; and the importance of a quality liquid, it is necessary to know the characteristics of the pyroligneous liquid (GAJIĆ et al., 2012).

Chemically, the pyroligneous liquid is formed by several compounds, among them: ketones; esters; aldehydes; acids; methanol; soluble and insoluble tar; phenolic chains and water (CAMPOS, 2007; RODRIGUES et al., 2016). These compounds are derived from the depolymerization and fragmentation reactions of the three main chemical constituents of the biomass: cellulose, lignin and hemicellulose, being constituted by different branches and sizes (ALMEIDA et al., 2015; EICHLER et al., 2015). In this context, the objective of this work was to qualitatively and quantitatively characterize the chemical compounds that make up the pyroligneous liquid obtained from the industrial scale carbonization of the peach stone.

\section{METHODOLOGY}

\section{Materials and reagents}

The dichloromethane (DCM), anhydrous sodium sulfate and sodium hydroxide reagents were of analytical grade. The standards of oleic acid, benzofuran, cresols (2-methylphenol, 3-methylphenol and 4methylphenol), guaiacol (2-methoxyphenol), phenol, 2-ethylphenol, 3-ethylphenol, 4-ethylphenol, 2methoxyvinylphenol, vanillin and the $\mathrm{N}$-methyl-N-trimethylsilyltrifluoracetamide derivative (MSTFA), were all purchased from Sigma Aldrich.

\section{Raw material}

The biomass used was the Prunus persica fruit core (peach stone) of different cultivars used in the production of canned peaches by industries in the region. This was provided by two canneries located in the city of Pelotas, in the state of Rio Grande do Sul, Brazil. The cores were first separated from impurities, stored in a waterproofed and covered place, and used in the carbonization process without previous grinding.

\section{Carbonization/generation of pyroligneous liquid}

The furnace used for the generation of charcoal has the capacity to burn 100 tons of biomass, working in batch and its structure is represented in accordance with Fig. 2 (a). The heat flow occurred in the upward direction and from the outer layer to the inner layer in the radial direction, with the help of pipes that allow the air to enter, Fig. 2 (b). The carbonization process was carried out on an industrial scale using the biomass 
without previous drying. The oven was fed by a rotary conveyor. The residence time in the kiln was about 20 hours, while the average carbonization temperature was $500^{\circ} \mathrm{C} \pm 20 \%$.
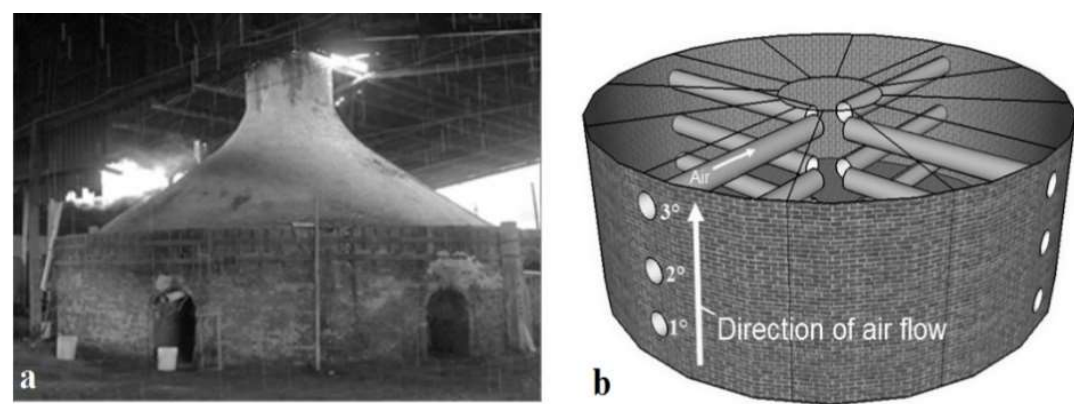

Fig. 2: (a) Kiln where carbonization occurs; (b) Internal representation of the carbonization furnace with the respective in lets and direction of the air flow.

The pyroligneous liquid was collected in 12 distinct points, which composes the condenser system and was collected in $1000 \mathrm{~L}$ capacity decantation tanks. The obtained liquid remained at rest for six months in order to separate a high molecular weight organic phase (tar) from the liquid fraction that constitutes the pyroligneous extract.

\section{Preliminary characterization}

For the preliminary characterization of the pyroligneous liquid the following parameters were evaluated: potential of hydrogen (Marconi pH meter MA 522/P); conductance (Conductivity meter Instrutherm CD 830); density (densimeter); color (visually); content of organic matter, through liquid-liquid extraction with DCM and gravimetric analysis (APHA, 2008); the titratable acidity (\% acetic acid) and tar content followed the methodology described by the Association of Producers of Natural Agriculture (APAN, 2018).

\section{Optimization of sample preparation for chromatography}

To optimize the extraction of organic fraction, $10 \mathrm{~g}$ of the pyroligneous liquid were extracted with 10 $\mathrm{mL}$ of distilled dichloromethane, for three consecutive times, totaling $30 \mathrm{~mL}$ of dichloromethane. Each $10 \mathrm{~mL}$ extract was percolated into columns with anhydrous sodium sulfate in order to remove the remaining aqueous fraction. The volume of each portion was separately reduced in a rotary evaporator and the final organic fraction had its volume corrected to $1 \mathrm{~mL}$ with distilled dichloromethane. Then, the extracts, without derivatization, were analyzed by gas chromatography coupled to mass spectrometry (GC-MS), injected in splitless mode.

\section{Derivatization of the sample}

The extracts were derivatized according to Orata (2015), with modifications, where $100 \mu \mathrm{L}$ of the organic fraction (diluted to $1 \mathrm{~mL}$ in DCM) was transferred to a $1 \mathrm{~mL}$ vial. Next, $20 \mu \mathrm{L}$ of the MSTFA derivatizing agent was added by shaking carefully and keeping in a sand bath at $80^{\circ} \mathrm{C}$ for thirty minutes. Then, when the sample reached the room temperature, its volume was corrected to $1 \mathrm{~mL}$ with distilled dichloromethane. 


\section{Recovery of samples}

In order to evaluate the recovery of the optimized liquid-liquid extraction, the procedure was repeated under the same conditions, however, the samples were fortified with $50 \mu \mathrm{L}$ of the standards vanillin, guaiacol, oleic acid, cresols and phenol, with a standard stock solution of $100 \mathrm{~g} \mathrm{~L}^{-1}$ in dichloromethane and bringing together all extracts from the three steps. At the end of the procedure, the concentration of the added standards corresponded to $500 \mathrm{mg} \mathrm{L}^{-1}$. According to the following equation, the recoveries were determined by discounting the quantities of the analytes present in the sample without fortification of the fortified samples: (analyte concentration in the fortified sample - analyte concentration in the non-fortified sample/500) x 100.

\section{Chromatographic analysis}

The derivatized extract was analyzed on GC/MS-Shimadzu QP2010 Ultra using an RTX-5MS (30 m x $0.25 \mathrm{~mm} \times 0.25 \mu \mathrm{m}$ ) column with the helium entrainment gas. $1 \mu \mathrm{l}$ of the sample was injected in split mode (1:20), with injector temperature of $280^{\circ} \mathrm{C}$. The following temperature program was used: initial temperature of $60{ }^{\circ} \mathrm{C}(10 \mathrm{~min})$, at a rate of $5{ }^{\circ} \mathrm{C} \mathrm{min}-1$ to $200{ }^{\circ} \mathrm{C}$, then the rate was increased to $10^{\circ} \mathrm{C} \mathrm{min}^{-1}$ to $300{ }^{\circ} \mathrm{C}$ where it remained for 12 minutes.

The mass spectrometer was operated in scan mode with the mass-to-charge ratio between $43-500$ $\mathrm{m} / \mathrm{z}$ with the total cycle time of $0.3 \mathrm{~s}$. The temperature of the ion source was $200{ }^{\circ} \mathrm{C}$, and the electron ionization potential at $70 \mathrm{eV}$. The GC/MS interface was maintained at $280^{\circ} \mathrm{C}$. Identification of the extracted organic fraction compounds was accomplished by comparing the mass spectra of the analytes found with those of the library (NIST/EPA/NIH - Mass Spectral library) of the equipment and by coincidence of the retention times with the standards. Only the peaks that showed similarity above $80 \%$ and area greater than $0.1 \%$ were considered.

For the quantification of the analytes, the calibration curves were constructed using the concentration range between 50 and $500 \mathrm{mg} \mathrm{L}^{-1}$. The $100 \mathrm{mg} \mathrm{L}^{-1}$ standard was analyzed eleven times to determine the accuracy of the method, while the mean value was used to evaluate the relative error. The limit of detection (LOD) was calculated using the sum of the mean of the blank signal plus three times its standard deviation, while the limit of quantification (LoQ) was obtained by adding the mean of the blank signal plus ten times its deviation standard, being considered $100 \%$ recovery and $10 \mathrm{~g}$ of sample (IUPAC, 1997). All procedures were performed in triplicate and accompanied by blank solutions.

To evaluate the accuracy of the method developed in this experiment RSD was estimated through five injections of the standard of phenols at concentrations of $100 \mathrm{mg} . \mathrm{L}-1$ for the derivatized standards (RIBANI et al., 2004; INMETRO, 2007). The accuracy of the method was estimated by the relative error through five injections of the standard mixture of phenols at concentrations of $100 \mathrm{mg} \mathrm{L}^{-1}$ for the derivatized standards (INMETRO, 2007). 


\section{RESULTS AND DISCUSSION}

Table 1 presents the results for the preliminary characterization of the pyroligneous liquid of this study, as well as the values specified for pyroligneous extracts of wood or bamboo marketed under the guidance of the APAN (2018).

Table 1: Physico-chemical characteristics of the pyroligneous liquid obtained from the peach stone and values recommended by APAN for extracts of wood or bamboo.

\begin{tabular}{|l|l|l|}
\hline CHARACTERISTIC & VALUES OBTAINED & RECOMMENDED VALUES \\
\hline $\mathrm{pH}$ & $2.89 \pm 0.11$ & $3.50 \pm 1.20$ \\
\hline Condutance $\left(\boldsymbol{\mu} \mathbf{S ~ c m}^{-1}\right)$ & $1190.67 \pm 2.52$ & $>3000.00$ \\
\hline Density $\left(\mathrm{kg} \mathrm{m}^{-\mathbf{3}}\right)$ & 1.01 & $1.002-1.010$ \\
\hline Color & Light yellow & Light yellow to red chocolate \\
\hline Acidity (\%acetic acid) & $2.98 \pm 0.07$ & $2.90-6.00$ \\
\hline Tar $(\%)$ & $5.47 \pm 0.34$ & -------- \\
\hline
\end{tabular}

The values found for density and acidity are in agreement with the values stipulated by the APAN (2018). However, the conductivity indicates low presence of dissociated salts in the sample in the form of ions or a more diluted extract (ABRATES, 2016). The $\mathrm{pH}$ of $2.89 \pm 0.11$ was below the value recommended by the APAN (2018), but agrees with Campos (2007), which cites the pH range around 2.3 to 3.0. The sample had a characteristic smoky odor, agreeing with Bridgwater (2003) and Campos (2007).

Fig. 3 shows the chromatograms for the three liquid-liquid extraction steps with dichloromethane. The reduction of the intensity and number of peaks are observed when comparing the first, second and third extraction batch indicating that the optimized procedure was sufficient to obtain the exhaustion of the organic fraction of the sample.

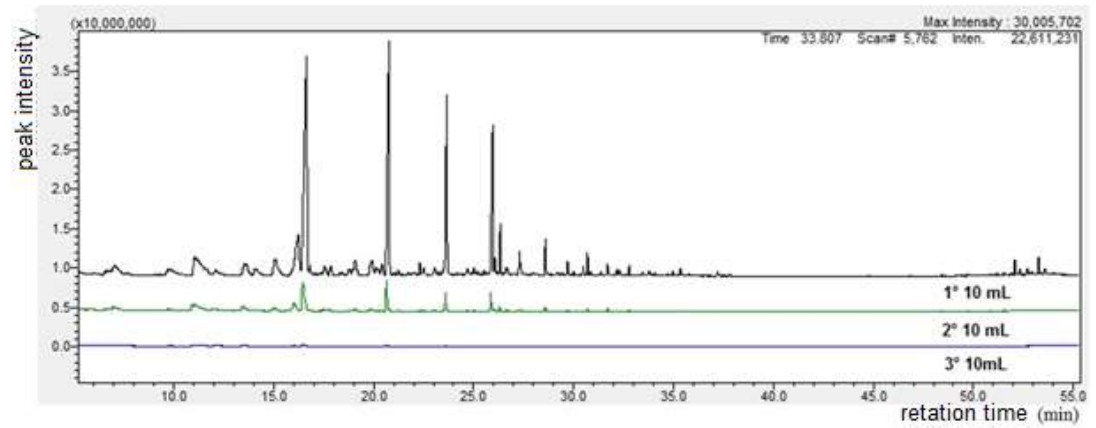

Fig 3: Chromatograms for the three sequential liquid-liquid extractions with DCM to non-derivatized sample.

After the optimization of the extraction process, it was possible to determine the organic matter content through the total mass of the extracts after the evaporation of the DCM, which was $1.81 \% \pm 0.09$. The literature reports average levels of the $10 \%$ of organic phase in the pyroligneous extract (ALVES et al., 2007). Therefore, the organic matter content in the sample studied is below the expected value, which again suggests that the extract is diluted, a result that agrees with the low conductivity and acidity. These results can be justified by the inefficient condensation system resulting in the loss of organic compounds to the atmosphere. The furnaces in which the pyroligneous liquid (PL) of this study was produced are structured and operated under the conditions for maximum charcoal yield. In this way, the PL appears in the process as a residue and its characterization can lead to a re-sizing of the carbonization process to produce a PL richer 
in organic compounds. The Table 2 presents the merit figures for the quantitative method of the organic fraction derivatized with MSTFA of PL analyzed by GC/MS.

Table 2: Figures of merit of the quantitative method.

\begin{tabular}{|l|l|l|l|l|l|l|l|l|}
\hline ANALITO & $\mathbf{a}$ & $\mathbf{b}$ & $\mathbf{r}^{\mathbf{2}}$ & $\mathbf{R S D}$ & $\mathbf{R e c}$ ( \pm RSD\%) & $\mathbf{R E}$ & LoQ & LoD \\
\hline Benzofuran & 21740.9 & -827451.9 & 0.996 & 2.3 & ------ & 7.5 & 0.7 & 0.2 \\
\hline Phenol & 72328.0 & -2652397.6 & 0.995 & 5.0 & $61.7 \pm 21.1$ & 6.9 & 0.2 & 0.1 \\
\hline 2-methylphenol & 2357.7 & -91751.7 & 0.993 & 2.6 & $74.8 \pm 19.4$ & 0.4 & 6.8 & 1.6 \\
\hline 4-methylphenol & 40351.6 & -1943595.3 & 0.988 & 4.3 & $111.0 \pm 17.8$ & 4.9 & 0.5 & 0.1 \\
\hline 3-methylphenol & 21581.7 & -1037318.0 & 0.988 & 4.7 & $113.8 \pm 16.9$ & 2.2 & 0.9 & 0.2 \\
\hline 2-ethylphenol & 91633.8 & -4981706.3 & 0.989 & 4.9 & ------- & 7.9 & 0.2 & 0.1 \\
\hline 4-ethylphenol & 82342.8 & -4969581.8 & 0.989 & 4.6 & ------- & 9.7 & 0.3 & 0.1 \\
\hline 2-methoxyphenol & 125919.7 & -6695826.9 & 0.989 & 3.9 & $71.6 \pm 23.5$ & 7.8 & 0.2 & 0.1 \\
\hline 3-ethylphenol & 123997.3 & -6920743.7 & 0.989 & 3.1 & ------ & 10.0 & 0.2 & 0.1 \\
\hline 2-methoxyvinylphenol & 9789.4 & -463304.2 & 0.989 & 1.3 & ------- & 6.5 & 1.7 & 0.4 \\
\hline Vanillin & 75405.8 & -4603721.7 & 0.987 & 1.8 & $114.5 \pm 12.9$ & 8.4 & 0.4 & 0.1 \\
\hline Oleic acid & 29908.7 & -58266.4 & 0.996 & 2.5 & $113.4 \pm 8.9$ & 4.5 & 0.5 & 0.2 \\
\hline
\end{tabular}

a. Angular coefficient. B. Linear coefficient. $r^{2}$. Coefficient of correlation. RSD. Relative standard deviation in \%. Rec (\%). Recovery in percentage. RE (\%). Relative error. LoD. Detection of limit ( $\left.\mathrm{mg} \mathrm{Kg}^{-1}\right)$. LoQ. Limit of quantification (mg Kg-1).

It is possible to observe, through the angular coefficient, that the chromatographic method is more sensitive for 2-methoxyphenol and 3-ethylphenol, which is the result of the higher response factor generated in the mass detector by TMS (trimethylsilyl) derivatives. The response factor also contributed to the lower values of detection and the quantification limits. The linear correlation coefficients for all the analytes were close to $\mathbf{0 . 9 9}$, indicating that the method behaves linearly for the concentration range studied. The derivatization process with the generation of trimethylsilyl derivatives promoted a higher interaction between the analytes with the stationary phase of polydimethylsiloxane with $5 \%$ of phenyl groups generating more symmetrical peaks, separation of different isomers and increase in the response factor, as observed in Fig 4.

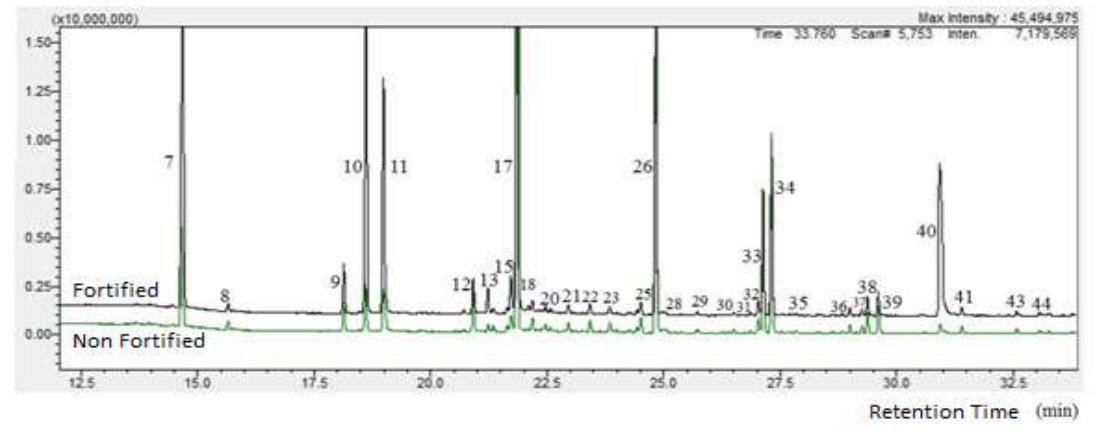

Fig 4: Partial chromatogram obtained by GC/MS analysis for the fortified and non-fortified samples of the organic fraction of the PL.

The recovery values were found to be between $61.7 \% \pm 21.1 \%$ for phenol and $114.5 \pm 12.9 \%$ for Vanillin. According to Pihlström et al. (2008) and Aragão et al. (2009), values above $70 \%$ are considered satisfactory. The low recovery presented by the phenol can be associated with its greater polarity, which makes it difficult to extract the aqueous matrix by dichloromethane, and also related to the losses in solvent evaporation stages (DOREA et al., 2017). Figure 4 shows the comparison between the chromatogram of a fortified sample and a non-fortified sample. It also demonstrates the increase in the peaks areas - 7, 9, 10, 11, 17, 40; as identified in Table 3 which corresponds to the fortified compounds. Relative errors were below 
$10 \%$ and the relative standard deviation was less than $5 \%$ of an accurate and precise method (OLIVEIRA et al., 2015). Table 3 presents the results for the qualitative and semiquantitative analyzes for the organic fraction of the pyroligneous liquid.

Table 3: Semi quantitative composition and compounds identified in the organic fraction of the PL.

\begin{tabular}{|c|c|c|c|c|c|}
\hline Peak & RT & Name & FORMULA & $\%$ AREA & CLASS \\
\hline 1 & 5.23 & 2-methylpropan-1-ol & $\mathrm{C}_{4} \mathrm{H}_{10} \mathrm{O}$ & 1.02 & Alcohol \\
\hline 2 & 5.62 & Butanoic acid & $\mathrm{C}_{4} \mathrm{H}_{8} \mathrm{O}_{2}$ & 1.24 & Acid \\
\hline 3 & 5.69 & Hydroxybutanone & $\mathrm{C}_{4} \mathrm{H}_{4} \mathrm{O}_{2}$ & 0.16 & Ketone \\
\hline 4 & 7.63 & Butenoic acid & $\mathrm{C}_{4} \mathrm{H}_{7} \mathrm{O}_{2}$ & 0.33 & Acid \\
\hline 5 & 7.70 & Pentanic acid & $\mathrm{C}_{5} \mathrm{H}_{10} \mathrm{O}_{2}$ & 0.17 & Acid \\
\hline 6 & 9.59 & 2,2-dimethylpropanol & $\mathrm{C}_{5} \mathrm{H}_{12} \mathrm{O}$ & 1.12 & Alcohol \\
\hline 7 & 14.65 & Phenol & $\mathrm{C}_{6} \mathrm{H}_{5} \mathrm{OH}$ & 6.62 & Phenol \\
\hline 8 & 15.64 & 2-butoxyethanol & $\mathrm{C}_{6} \mathrm{H}_{14} \mathrm{O}_{2}$ & 0.53 & Alcohol \\
\hline 9 & 18.12 & 2-methylphenol & $\mathrm{C}_{7} \mathrm{H}_{8} \mathrm{O}$ & 1.69 & Phenol \\
\hline 10 & 18.59 & 4-methylphenol & $\mathrm{C}_{7} \mathrm{H}_{8} \mathrm{O}$ & 2.90 & Phenol \\
\hline 11 & 18.97 & 3-methylphenol & $\mathrm{C}_{7} \mathrm{H}_{8} \mathrm{O}$ & 3.29 & Phenol \\
\hline 12 & 20.90 & Hexadienoic acid & $\mathrm{C}_{6} \mathrm{H}_{8} \mathrm{O}_{2}$ & 2.29 & Acid \\
\hline 13 & 21.22 & 2,3-dimethylphenol & $\mathrm{C}_{8} \mathrm{H}_{10} \mathrm{O}$ & 0.36 & Phenol \\
\hline 14 & 21.33 & Trihydroxybenzene (isomer 1) & $\mathrm{C}_{6} \mathrm{H}_{9} \mathrm{O}_{3}$ & 0.30 & Phenol \\
\hline 15 & 21.64 & 4-ethylphenol & $\mathrm{C}_{8} \mathrm{H}_{10} \mathrm{O}$ & 0.30 & Phenol \\
\hline 16 & 21.72 & Dimethylphenol (isomer 1) & $\mathrm{C}_{8} \mathrm{H}_{10} \mathrm{O}$ & 1.10 & Phenol \\
\hline 17 & 21.84 & 2-methoxyphenol & $\mathrm{C}_{6} \mathrm{H}_{5} \mathrm{O}_{2}$ & 23.62 & Phenol \\
\hline 18 & 22.17 & 3-ethylphenol & $\mathrm{C}_{8} \mathrm{H}_{10} \mathrm{O}$ & 0.68 & Phenol \\
\hline 19 & 22.45 & Benzoic acid & $\mathrm{C}_{7} \mathrm{H}_{6} \mathrm{O}_{2}$ & 0.28 & Acid \\
\hline 20 & 22.56 & Dimethylphenol (isomer 2) & $\mathrm{C}_{8} \mathrm{H}_{10} \mathrm{O}$ & 0.19 & Phenol \\
\hline 21 & 22.95 & Dimethylphenol (isomer 3) & $\mathrm{C}_{8} \mathrm{H}_{10} \mathrm{O}$ & 0.51 & Phenol \\
\hline 22 & 23.41 & Trihydroxybenzene (isomer 2) & $\mathrm{C}_{6} \mathrm{H}_{9} \mathrm{O}_{3}$ & 0.68 & Phenol \\
\hline 23 & 23.84 & Maltol & $\mathrm{C}_{6} \mathrm{H}_{6} \mathrm{O}_{3}$ & 0.56 & Enol \\
\hline 24 & 24.42 & Methoxymethylphenol (isomer 1) & $\mathrm{C}_{8} \mathrm{H}_{10} \mathrm{O}_{2}$ & 0.36 & Phenol \\
\hline 25 & 24.50 & Methoxymethylphenol (isomer 2) & $\mathrm{C}_{8} \mathrm{H}_{10} \mathrm{O}_{2}$ & 0.91 & Phenol \\
\hline 26 & 24.82 & Methoxymethylphenol (isomer 3) & $\mathrm{C}_{8} \mathrm{H}_{10} \mathrm{O}_{2}$ & 21.66 & Phenol \\
\hline 27 & 24.99 & 2-propylphenol & $\mathrm{C}_{9} \mathrm{H}_{12} \mathrm{O}$ & 0.52 & Phenol \\
\hline 28 & 25.04 & 2-Methylbenzoic acid & $\mathrm{C}_{8} \mathrm{H}_{8} \mathrm{O}_{2}$ & 0.22 & Acid \\
\hline 29 & 25.71 & Nona-3,6-dien-1-ol & $\mathrm{C}_{9} \mathrm{H}_{16} \mathrm{O}$ & 0.22 & Alcohol \\
\hline 30 & 26.50 & Dimethoxyphenol (isomer 1) & $\mathrm{C}_{6} \mathrm{H}_{4} \mathrm{O}_{3}$ & 0.18 & Phenol \\
\hline 31 & 26.86 & Vanilina (isomer 1) & $\mathrm{C}_{8} \mathrm{H}_{8} \mathrm{O}_{3}$ & 0.16 & Aldehyde/phenol \\
\hline 32 & 27.03 & 4-methyl-benzene-1.2-diol & $\mathrm{C}_{7} \mathrm{H}_{9} \mathrm{O}_{2}$ & 0.82 & Phenol \\
\hline 33 & 27.13 & Vanillin (isomer 2) & $\mathrm{C}_{8} \mathrm{H}_{8} \mathrm{O}_{3}$ & 7.54 & Aldehyde/phenol \\
\hline 34 & 27.31 & Dimethoxyphenol (isomer 2) & $\mathrm{C}_{6} \mathrm{H}_{4} \mathrm{O}_{3}$ & 10.87 & Phenol \\
\hline 35 & 27.82 & Vanillin (isomer 3) & $\mathrm{C}_{8} \mathrm{H}_{8} \mathrm{O}_{3}$ & 0.14 & Aldehyde/phenol \\
\hline 36 & 28.99 & o-hydroxyethylphenol & $\mathrm{C}_{8} \mathrm{H}_{10} \mathrm{O}_{2}$ & 0.45 & Phenol \\
\hline 37 & 29.25 & Eugenol & $\mathrm{C}_{10} \mathrm{H}_{12} \mathrm{O}_{2}$ & 0.41 & Phenol \\
\hline 38 & 29.37 & N.I. & ------ & 1.12 & Others \\
\hline 39 & 29.60 & N.I. & $\begin{array}{ll}----- \\
\end{array}$ & 1.53 & Others \\
\hline 40 & 30.93 & Vanillin & $\mathrm{C}_{8} \mathrm{H}_{8} \mathrm{O}_{3}$ & 0.65 & Aldehyde/phenol \\
\hline 41 & 31.40 & 3,5-dimethoxy-4-hydroxybenzaldehyde & $\mathrm{C}_{9} \mathrm{H}_{10} \mathrm{O}_{4}$ & 0.35 & Aldehyde/phenol \\
\hline 42 & 31.44 & Methyl 3-hydroxy-4-methoxybenzoate & $\mathrm{C}_{9} \mathrm{H}_{10} \mathrm{O}_{4}$ & 0.15 & Ester/phenol \\
\hline 43 & 32.57 & 2-Hydroxy-3-methylbenzoic acid & $\mathrm{C}_{8} \mathrm{H}_{8} \mathrm{O}_{3}$ & 0.25 & Acid/phenol \\
\hline 44 & 33.04 & 4-hydroxy-3-methoxyphenylethanone (apocynin) & $\mathrm{C}_{9} \mathrm{H}_{10} \mathrm{O}_{3}$ & 0.19 & Ketone \\
\hline 45 & 35.62 & N.I. & ------ & 0.44 & Others \\
\hline 46 & 35.63 & N.I. & $\begin{array}{ll}---- \\
--1\end{array}$ & 0.40 & Others \\
\hline 47 & 36.67 & N.I. & 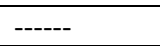 & 0.12 & Others \\
\hline 48 & 37.03 & Methyl 2 (3-hydroxy-4-methoxyphenyl) -2-hydroxyethanoate & $\mathrm{C}_{10} \mathrm{H}_{12} \mathrm{O}_{5}$ & 0.12 & Ester/phenol \\
\hline 49 & 37.6 & 3 (4-hydroxy-3-methoxyphenyl) propane-1-ol & $\mathrm{C}_{10} \mathrm{H}_{14} \mathrm{O}_{3}$ & 0.20 & Alcohol/phenol \\
\hline
\end{tabular}
${ }^{\mathrm{a} R T}(\min )$ : Retention time in minutes.

A total of 49 peaks with areas greater than $0.1 \%$ were detected. In the organic fraction of the pyroligneous liquid, 44 compounds were identified with the similarity of $80 \%$. Fig. 5 shows the percentage in area and number of compounds of each chemical class constituent of the organic fraction of pyroligneous 
liquid studied. In the class, other denominates were reunited functions whose compounds presented similarities inferior to $80 \%$.

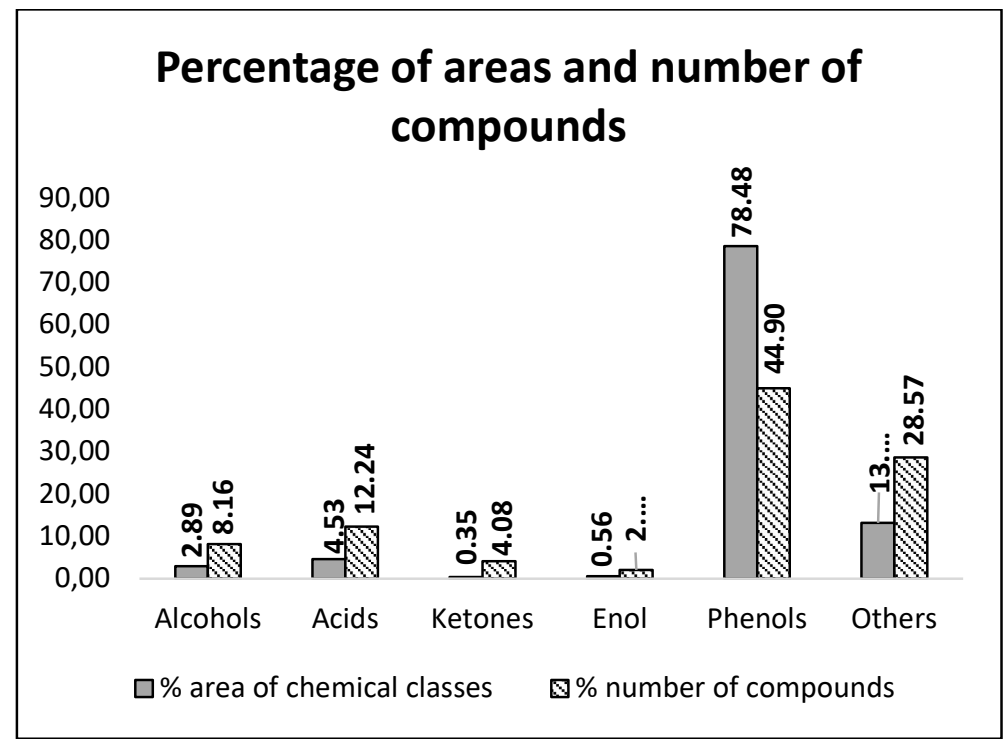

Fig 5: Percentage of areas and number of compounds present in each chemical class identified in PL.

It is found that the phenols are major in both area (approximately $80 \%)$ and in number $(44.90 \%$ of the identified compounds). This fact occurs due to the high content of lignin present in the biomass used (MIGLIORINI et al., 2013; ZHANG et al., 2013; BISPO et al., 2016). According to Souza, et al. (2012), woody materials such as peach stone are rich in lignin and cellulose and when carbonized, they are thermally degraded in ketones, alcohols, furan derivatives and phenolic compounds. Among the phenols identified in this study, two of them stand out: 2-methoxyphenol and methoxymethylphenol (isomer), with $23.62 \%$ and $21.66 \%$ respectively. According to Migliorini et al. (2013), phenols substituted by methoxy groups originate from lignin. These results agree with those described by Moraes et al. (2012) in the peach stone bio-oil obtained by rapid pyrolysis, Özbay et al. (2008), who performed the bio-oil characterization of the peach pulp using the GC-MS and Migliorini et al. (2013) who found 277 compounds in the bio-oil sample of pyrolysis of the peach stone by $\mathrm{GC} \times \mathrm{GC} / \mathrm{TOFMS}$.

The chemical composition of the extracts obtained depends on the characteristics of the source material, and also on the conditions under which the biomass is exposed. In addition, different biomasses produce bio-oils with different constituents and/or quantities (MA et al., 2013). It should be noted that for this study the pyroligneous liquid was obtained by carbonization, while the studies presented for comparison were obtained by pyrolysis. From the totality of compounds identified in the qualitative analysis, the phenolic compounds that presented the highest percentage of relative area were quantified. The concentrations of the analytes in $\mathrm{mg}^{\mathrm{kg}}{ }^{-1}$ in the organic fraction of pyroligneous liquid are shown in Fig 6.

Among the quantified compounds, 2-methoxyphenol with $237.6 \mathrm{mg} \mathrm{kg}^{-1} \pm 10.3 \%$ was the majority, followed by phenol and cresols. Among their chemical properties, the phenols present a great versatility of use as starting material and as intermediates in the production of molecules of greater complexity, as well as in the production of phenolic resins (MIGLIORINI et al., 2013). However, in the concentration ranges 
detected and considering it to be an aqueous matrix, some studies have proposed its application as a fungicide (SUMANATRAKUL et al., 2015).

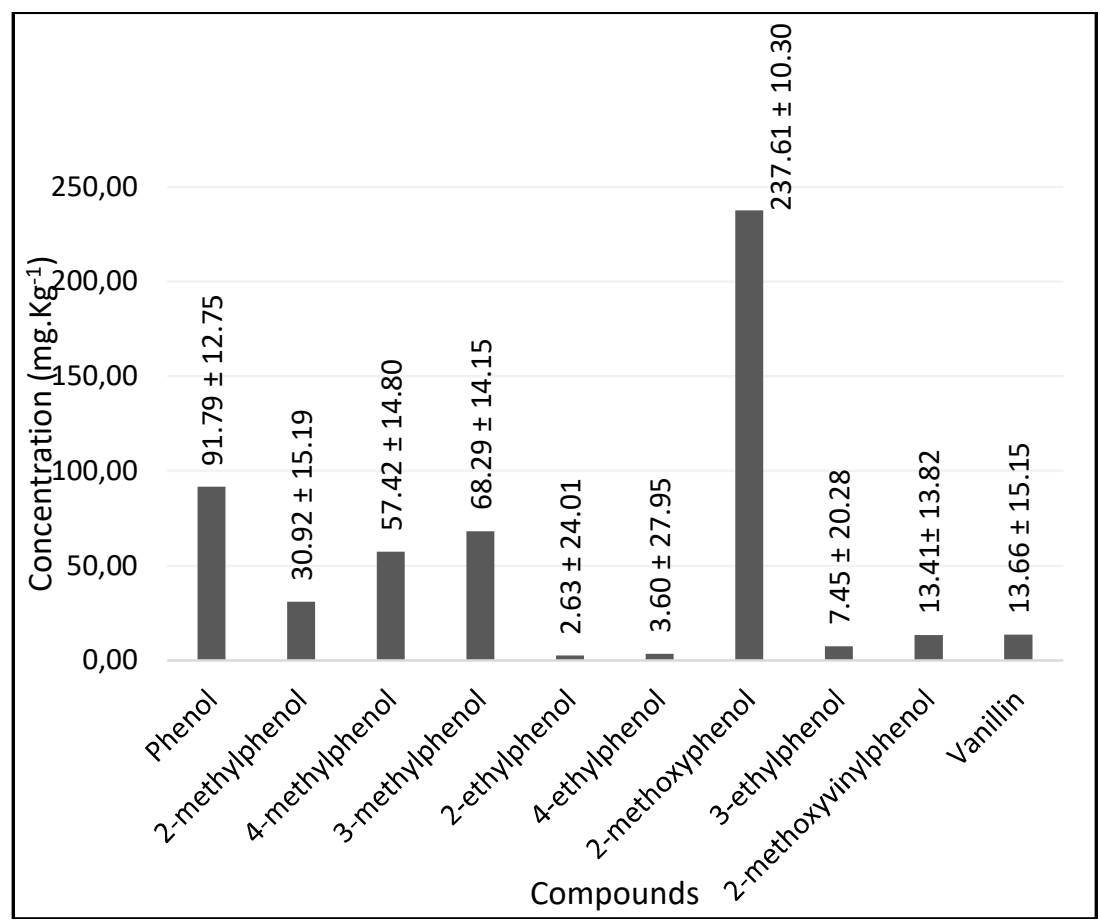

Fig 6: Concentration, in $\mathrm{mg} \mathrm{Kg}^{-1} \pm \mathrm{RSD}(\%)$ of the main compounds present in the PL sample.

Guaiacol (methoxyphenol) causes darkening in the sample when exposed to air and light and can be used as an indicator for enzymes, expectorant, antiseptic and anesthetic. In addition, hydroxybutanone and maltol, compounds identified in the qualitative analysis are widely used as additives in food production to enhance flavors and in medicinal products (HUANG, 2011).

In the case of the major compound 2-methoxyphenol with $237.61 \mathrm{mg} \cdot \mathrm{Kg}^{-1}$, the amount of woody endocarp produced in the year (4,048 tons) and the estimate of the pyroligneous liquid generated (35\%) cited by Sena et al. (2014), the average yield of only this compound would be about 336 tons/year. Aiming at the possible industrial applications for this compound and verifying that there is a direct and beneficial influence on the aggregation of the value of the agroindustrial residue, it is verified that the production of the studied co-product has great relevance, when the process used occurs within the expected standards.

However, there are not specific definitions yet or standards for obtaining pyroligneous liquid from peach stone, which specify the constituents, characteristics and benefits of the compounds, to be accepted in the consumer market. For this, it is necessary to implement quality control to ensure the safety and efficiency of this product. However, to apply standards that quantify the components of the PL, it is necessary to evaluate a greater number of samples obtained by different methods and conditions of production and types / quality of the biomass.

\section{CONCLUSIONS}

The analysis of the pyroligneous liquid derived from the carbonization allowed us to conclude that this biomass has the potential to obtain chemical compounds of economic interest, such as: phenols, ketones, 
acids and alcohols. With a predominance of phenols (approximately $80 \%$ ), it has important applications as raw materials and in the development of commercial products. This justifies its production and use and consequently reducing the environmental impact and adding value to the agroindustrial residue.

ACKNOWLEDGEMENTS: The authors thank Pro-rector of research and post-graduation (PROPESP-IFSUL), the National council for scientific and technological development (CNPq) and the BIOQUIM Company - Pelotas RS - for technical and financial support.

\section{REFERENCES}

ABRATES, A. C. N.. Obtenção de sistemas de macroemulsionados a partir de óleos vegetais para incorporar extrato seco de punica granatum. Dissertation (Master's degree) - Universidade Federal do Rio Grande do Norte, Natal, 2016

ALMEIDA, A. M. C.; OLIVEIRA, E.; CALEGARI, L.; MEDEIROS, P. N.; PIMENTA, A. S.. Avaliação Físico-Química e Energética da Madeira das Espécies Piptadenia stipulacea (Benth.) Ducke $E$ Amburana cearensis (Allemao) A. C. Smith de ocorrência no semiárido nordestino brasileiro. Ciência Florestal, v.25, n.1, 2015. DOI: http://doi.org/10.5902/1980509817474

ALVES, M.; CAZETTA, J. O.; NUNES, M. A.; DE OLIVEIRA, C. A. L.; COLOMBI, C. A.. Ação de diferentes preparações de extrato pirolenhoso sobre Brevipalpus phoenicis (GEIJSKES). Revista Brasileira de Fruticultura, v.29, n.2, p.382-385, 2007. DOI: http://dx.doi.org/10.1590/S0100$\underline{29452007000200037}$

APAN. Associação de Produtores de Agricultura Natural. Extrato Pirolenhoso: Abrangência e objetivos da norma. APAN, 2018.

APHA. Standard Methods for the Examination of Water and Wastewater. 21 edition. APHA, 2008.

ARAGÃO, N. M.; VELOSO, M. C. C.; ANDRADE, J. B.. Validação de métodos cromatográficos de análise: um experimento de fácil aplicação utilizando cromatografia líquida de alta eficiência (CLAE) e os princípios da 'Química Verde' na determinação de metilxantinas em bebidas. Química Nova, v.32, n.9, p.2476-2481, 2009. DOI:

http://dx.doi.org/10.1590/S0100-40422009000900043

BAE, Y. J.; RYU, C.; JEON, J. K.; PARK, J.; SUH, D. J.; SUH, Y. W.; PARK, Y. K.. The characteristics of bio-oil produced from the pyrolysis of three marine macroalgae. Bioresource Technology, v.102, n.3, p.3512-3520, 2011. DOI: https://doi.org/10.1016/j.biortech.2010.11.023

BISPO, M. D.; BARROS, J. A. S.; TOMASINI, D.; PRIMAZ, C.; CARAMÃO, E. B; DARIVA, C.; KRAUSE, L. C.. Pyrolysis of Agroindustrial Residues of Coffee, Sugarcane Straw and Coconut-Fibers in a Semi-pilot Plant for Production of Biooils: Gas Chromatographic Characterization. Journal of Earth Science and Engineering, v.6, n.5, 2016. DOI: http://doi.org/10.17265/2159-581x/2016.05.001
BRIDGWATER, A. V.. Renewable fuels and chemicals by thermal processing of biomass. Chemical Engineering Journal, v.91, n.2-3, p.87-102, 2003.

BRIDGWATER, T.. Biomass for energy. Science of Food and Agriculture, v.86, n.12, p.1755-1768, 2006.

CAMPOS, A. D.. Técnicas para produção de extrato pirolenhoso para uso agrícola, Pelotas/RS. Ministério da Agricultura e Pecuária, v.65, p.1-8, 2007.

DIAS, G. F.. Atividades interdisciplinares de educação ambiental. In: PARTE I: PERCEBENDO ELEMENTOS DO HÁBITAT HUMANO. Anais. Global, 2015. p.224.

DIMAKIS, A.; BIBERACHER, M.; DOMINGUEZ, J.; FIORESE, G.; GADOCHA, S.; GNANSOUNOU, E.; GUARISO, G.; KARTALIDIS, A.; PANICHELLI, L.; PINEDO, I.; ROBBA, M.. Methods and tools to evaluate the availability of renewable energy sources, Renewable Sustainable Energy Reviews, v.15, n.2, p.1182-1200, 2011. DOI:

http://doi.org/10.1016/j.rser.2010.09.049

DOREA, H. S.; GOMES, I. A.; PRATA, V. M.; MOREIRA, C. O.; SOUZA, M. R. R.. Determination of 11-nor-9-carboxy-9tetrahydrocannabinol in human urine by liquid-liquid dispersion microextraction with solidification of the floating organic droplet and online derivation in the chromatographic injection system. Scientia Plena, v.13, n.2, p.1-12, 2017. DOI:

http://doi:10.14808/sci.plena.2017.027201

EICHLER, P.; SANTOS, F.; TOLEDO, M.; ZERBIN, P.; SCHMITZ, G.; ALVES, C.; RIES, L.; GOMES, F.. Produção do biometanol via gaseificação de biomassa lignocelulósica. Química Nova, v.38, n.6, p.828-835, 2015. DOI:

http://dx.doi.org/10.5935/0100-4042.20150088

FERREIRA, J. C.; STAHELIN, T. S. F.; VALIN, M.; BRAND, M. A.; MUÑIZ, G. I. B.. Qualificação da biomassa em povoamentos florestais de Pinus taeda. Floresta, v.46, n.2, p.269-276, 2016. DOI: http://dx.doi.org/10.5380/rf.v46i2.41208

GAJIĆ, A.; KOCH, H. J.. Sugar beet ( L.) growth reduction caused by hydrochar is related to nitrogen supply. Journal of Environmental Quality, v.41, n.4, p.1067-1075, 2012. DOI: http://doi.org/10.2134/jeq2011.0237

HEYLMANN, K. K. A.. Produção, caracterização e aplicação de carvão ativado de caroço de pêssego no tratamento de 
efluente têxtil. Monografia (Graduação) - Universidade Federal de Pelotas, Pelotas, 2015.

HUANG, J.. Hydroquinone modified hyper-cross-linked resin to be used as a polymeric adsorbent for adsorption of salicylic acid from aqueous solution. Journal of Applied Polymer Science, v.121, n.6, p.3717-3723, 2011. DOI: http://doi.org/10.1002/app.33673

INMETRO. Instituto Nacional de Metrologia, Qualidade e Tecnologia. Orientação sobre validação de métodos Químicos: Documento de caráter orientativo. 2007.

IUPAC. International Union of Pure and Applied Chemistry. Chemistry Compendium of Chemical Terminology. 2 ed. IUPAC, 1997.

KOPP, V. V.; LIENDO, M. A.; ZOTTIS, R.; RODRIGUES, L. M.; HERNANDEZ, W.. Aproveitamento da sílica da cinza da casca do arroz para obtenção de vidro bioativo. In: SALÃO INTERNACIONAL DE ENSINO, PESQUISA E EXTENSÃO, 7 Anais. Bagé: Universidade Federal do Pampa, 2015.

MA, C.; SONG, K.; YU, J.; YANG, L.; ZHAO, C.; WANG, W.; ZU, Y.. Pyrolysis process and antioxidant activity of pyroligneous acid from Rosmarinus officinalis leaves. Journal of Analytical and Applied Pyrolysis, v.104, p.38-47, 2013. DOI: http://doi.org/10.1016/j.jaap.2013.09.011

MIGLIORINI, M. V.; MORAES, M. S. A.; MACHADO, M. E.; CARAMÃO, E. B.. Characterization of phenols in bio-oil of peach stone pyrolysis by GC / MS and GCxGC / TOFMS. Science Chromatograpy, v.5, n.1, p.47-65, 2013. DOI: http://dx.doi.org/10.4322/sc.2013.006

MORAES, M. S. A.. Avaliação da composição química de bioóleos de pirólise de diferentes biomassas utilizando a cromatografia gasosa monodimensional e a bidimensional abrangente. Dissertation (Master's degree) - Universidade Federal do Rio Grande do Sul, Porto Alegre, 2012.

MORVOVÁ, M.; MORVA, I.; JANDA, M.; HANIC, F.; LUKÁÈ, P.. Combustion and carbonisation exhaust utilisation in electric discharge and its relation to prebiotic chemistry. International Journal of Mass Spectrometry, v.223-224, n.2 p.613-625, 2003. DOI: http://doi.org/10.1016/S13873806(02)00935-1

OLIVEIRA, C. M. R. C. M.; CARDOSO, K. M.; SOUZA, M. M.; SANTOS, J. S.; SANTOS, M. L. P.. Validation of a practical method for the determination of amoxicillin levels in natural waters by CLAE-UV and its application in environmental quality. Institute Magazine Adolfo Lutz, v.74, n.4, p.361-370, 2015.

ORATA, F.. Derivatization Reactions and Reagents for Gas Chromatography Analysis. Advanced Gas Chromatography Progress in Agricultural, Biomedical and Industrial Applications. 2012.
ÖZBAY, N.; APAYDIN-VAROL, E.; UZUN, B. B.; PÜTÜN, A. E.. Characterization of bio-oil obtained from fruit pulp pyrolysis. Energy, v.33, n.8, p.1233-1240, 2008. DOI: http://doi.org/10.1016/j.energy.2008.04.006

PIHLSTRÖM, T.; ANASTASSIADES, M.; ANDERSSON, A.; CUHRA, P.; KOK, A.; DURCANSKA, J.; POULSEN, M. E.; FERNÁNDEZ-ALBA, A. R.; GAMÓN, M.; LIPPOLD, R.; MALATO, O.; MEDINA, P.; PELOSI, P.; RAVIO, P.; REUNOLDS, S.; VALVERDE, A.; ZACHARIAE, W.. Method Validation and Quality Control Procedures for Pesticide Residues Analysis in Food and Feed. Document No. SANCO/2007/3131. 2007.

RIBANI, M.; BOTTOLI, C. B. G.; COLLINS, C. H.; SALES, I. C.; MELO, L. F. C.. Validação em métodos cromatográficos e eletroforéticos. Química Nova, v.27, n.5, p.771-780, 2004. DOI: http://dx.doi.org/10.1590/S0100-40422004000500017

RODRIGUES, D. A.; FREITAS, R. R.; LIRA, T. S.; XAVIER, T. P. Analysis of the implantation of a plant pyrolysis of macadamia nuts, Brazil. Journal of Production Engineering, v.2, n.1, p.1-11, 2016.

SENA, M. F. M.; ANDADRE, A. M.; FILHO, S. T.; SANTOS, F. R.; PEREIRA, L. F.. Potencialidades do extrato pirolenhoso: práticas de caracterização. Revista Eletrônica em Gestão Educação e Tecnologia Ambiental, v.18, p.41-44, 2014. DOI: http://dx.doi.org/10.5902/2236117013808

SOUZA, J. B. G.; RÉ-POPPI, N.; RAPOSO, J. L.. Characterization of pyroligneous acid used in agriculture by gas chromatography-mass spectrometry. Journal of the Brazilian Chemical Society, v.23, n.4, 2012. DOI: http://doi.org/10.1590/s0103-50532012000400005

SUMANATRAKUL, P.; KONGSUNE, P.; CHOTITHAM, L.; SUKTO, U.. Utilization of Dendrocalamus Asper Backer Bamboo Charcoal and Pyroligneous Acid. Energy Procedia, v.79, p.691-696, 2015. DOI: http://doi.org/10.1016/j.egypro.2015.11.558

TORRES, N. H.; AMÉRICO, J. H. P.; ROMANHOLO, L. F. F.; RIBEIRO-GRANJA, A. C.; HARDER, M. N. C.. Aproveitamento sustentável dos subprodutos da madeira e das folhas para extração de óleos essenciais. Bioenergia em Revista: diálogos, v.4, n.1, p.10-22, 2014.

VIEIRA, R. P.; MOKOCHINSKI, J. B.; PALMA, L. C.; LIDOINO, V G.; HALASZ, M. R. T.. Caracterização química do extrato pirolenhoso oriundo da carbonização. In: CONGRESSO BRASILEIRO DE ENGENHARIA QUÍMICA, 20. Anais. Florianópolis, 2015. DOI: http://doi.org/10.5151/chemengcobeq2014-0450-25442-180041

ZHANG, W.; MA, Y.; WANG, C.; LI, S.; ZHANG, M.; CHU, F.. Preparation and properties of lignin-phenol-formaldehyde resins based on different biorefinery residues of agricultural biomass. Industrial Crops and Products, v.43, p.326-333, 2013. DOI: http://doi.org/10.1016/i.indcrop.2012.07.037

A CBPC - Companhia Brasileira de Produção Científica (CNPJ: 11.221.422/0001-03) detém os direitos materiais desta publicação. Os direitos referem-se à publicação do trabalho em qualquer parte do mundo, incluindo os direitos às renovações, expansões e disseminações da contribuição, bem como outros direitos subsidiários. Todos os trabalhos publicados eletronicamente poderão posteriormente ser publicados em coletâneas impressas sob coordenação da Sustenere Publishing, da Companhia Brasileira de Produção Científica e seus parceiros autorizados. Os (as) autores (as) preservam os direitos autorais, mas não têm permissão para a publicação da contribuição em outro meio, impresso ou digital, em português ou em tradução. 